\title{
Campaign Effectiveness on Communication Engineering Behavior in Use of Sinovac Covid-19 Vaccine
}

\section{SRI DESTI PURWATININGSIH 1, ILONA VICENOVIE OISINA SITUMEANG 2}

\author{
Persada Indonesia University YAI Diponogoro Street no 74 Salemba Central Jakarta 10340 \\ psridesti@yahoo.com \\ ilonaoisina@yahoo.com
}

Article History: Received: 11 January 2021; Accepted: 27 February 2021; Published online: 5 April 2021

\begin{abstract}
The spread of the Covid-19 virus in Indonesia is increasingly widespread and more than 1 million people have been infected with the Coronavirus. The Indonesian government is making various efforts to slow the spread and rate of the Coronavirus and one of them is by campaigning for the Sinovac vaccine. Various campaigns on the importance of vaccination as the most effective effort to prevent the Covid-19 pandemic from spreading have been carried out di Indonesia. This research uses a quantitative approach, with the nature of the research is explanatory research. This research method uses a survey research type. The population in this study were members of the Istiqomah Taklim Council, and the sample used in this study amounted to 30 people. Using non-probability sampling, with the Accidental Sampling technique. The results showed that the campaign effectiveness of using the Covid-19 Sinovac vaccine had a major or significant effect on people's behavior in receiving the vaccine.
\end{abstract}

Keywords: Effectiveness, Campaign, Communication Engineering Behavior, Sinovac Vaccine

\section{INTRODUCTION}

Currently, the world is facing health problems where there has been the spread of the coronavirus (Covid19) outbreak which has infected almost all countries in the world. On 30 January 2020, the World Health Organization (WHO) decided the Covid-19 case as a Public Health Emergency of International Concern (PHEIC) / Public Health Emergency Concerns the World (KKMMD) (CDC, 2020). March 11, 2020 (WHO) declared Covid19 a pandemic. To date, there are 65 countries infected with the coronavirus. As of April 29, 2020, the number of people infected with Covid-19 in the world has reached 3.1 million people (World Health Organization, 2020) and continues to grow today.

The Covid-19 outbreak first occurred in Wuhan, China December 2019, until April 2020 spread to 210 countries, with its very rapid spread, coupled with very high human mobility across national borders, making this virus very dangerous. Based on Worldometer data until April 23, 2020, positive cases reached 2.7 million worldwide, with the United States, Spain, and Italy in the top three rankings as the countries with the highest cases in the world, leaving China which is the starting place for the spread of this virus. (worldometers.info, 2020).Covid19 became the world's largest non-natural disaster in 2020. The first time it broke out in Wuhan, China then spread to other countries including Indonesia (Juditha, 2020).

In Indonesia As of March 19, 2020, 214,894 people were infected with the coronavirus, 8,732 people died and 83,313 patients recovered. (Aida, 2020). The spread of Covid-19 in Indonesia is starting to become unstoppable. The Indonesian government has made various efforts to slow the pace of the Coronavirus, including working, studying, worshiping at home, Large-Scale Social Restrictions (PSBB), stopping the mode of transportation, prohibiting going home. But this pandemic is not over (Juditha, 2020). The government issued a circular on March 18, 2020, to reduce outdoor activities in all fields to reduce the spread of the coronavirus (Goddess, 2020)

The condition of the COVID-19 pandemic has a very serious impact on the structure of people's lives in the health, economy, and social sectors. In Indonesia, the Government issued a disaster emergency status from 29 
February 2020 to 29 May 2020 related to this virus pandemic with a total time of 91 days. (Koesmawardhani, 2020). Also, it has an impact on changes in the activities of the global community in various fields of life such as the economic, social, tourism, and education sectors (Goddess, 2020) From time to time, patients who are confirmed positive for Covid-19 are increasing in various countries and also in Indonesia, almost a large part of the world community is in uncertainty. This situation caused panic and severe psychological stress. (Juditha, 2020)

To deal with the epidemic that does not drag on and becomes more widespread, countries in the world are currently competing to make vaccines that are effective in preventing the spread of Covid-19 through a series of strong evidence-based scientific stages. As of August 25, 2020, there are 31 vaccine candidates currently in the clinical stage, with 6 vaccine candidates developed by the University of Oxford / AstraZeneca, Sinovac Biotech, Wuhan Institute of Biological Products / Sinopharm, Beijing Institute of Biological Products / Sinopharm, Moderna. / NIAID and BioNTech / Fosun Pharma / Pfizer. Meanwhile, 142 vaccine candidates are at the preclinical stage. (World Health Organization, 2020).

Responding to these challenges, the state undertakes non-medical interventions through the use of social vaccines, namely a metaphor to describe a series of social and behavioral actions that the government (state) can use to increase public awareness. This can be done through social mobilization, which is the process by which people are organized to enable them to think and act collectively based on developments within their communities, for example, to oppose unhealthy practices and behavior, or how to increase self-resilience. as well as encouraging advocacy for change, which in turn encourages the political will (political will) of every element in the country to take appropriate actions in the interests of society (Baum et al., 2009).

Scientists in various countries continue to compete, exhausting their energy and mind to race against time to find a vaccine that can cure diseases (Deutsch, 2020). In Indonesia, Sinovac is working with Bio Farma to produce a coronavirus vaccine. This Beijing-based coronavirus vaccine has passed phase I and II clinical trials. "The transfer of production technology for the Covid-19 vaccine from Sinovac to Bio Farma is being carried out during the third phase of clinical trials," (Rizki, 2020). From safety data, this vaccine is quite safe. There were no serious side effects associated with the use of this vaccine. Meanwhile, immunogenicity has also shown a good level of antibody formation in the body. (Lucia Rizka, 2021).

Several factors need to be considered in the plan to carry out mass vaccination in 2021. Because many people have doubts about the halalness of the vaccine, it is necessary to carry out various campaigns regarding the importance of vaccination as the most effective effort to prevent the disease and the dangers of the Covid-19 pandemic. (Rahmi Yuningsih, 2020). The country's response in implementing social vaccine policies is considered effective to prevent and overcome the risk of spreading the coronavirus. It is evident that there has been a decrease in the number of positive cases in countries with 'social vaccines', which means that the country is less able to control the situation'. However, it needs to be understood, when this social vaccine is applied by the government (country) during a pandemic, its effectiveness is largely determined by the process of information dissemination and collection and use of accurate and transparent information regarding the risk of infection. (Drishti, 2020),

Vaccination programs usually reap pros and cons and even become politicized. One resistance to vaccination revolves around the fear of the ingredients in the vaccine. Another reason for rejection is the notion that the immune mechanism that develops after exposure to the disease is stronger than the "artificial" immunity that is trained through vaccination. The emergence of refusal because vaccination is considered a personal choice, not an obligation that must be carried out because of a government program. (Mahatma Chryshna, 2020). There are pros and cons in the community regarding the covid-19 vaccination program, the reason is that the matter of halal is still in doubt,(Asrorun, 2020)In response to the pros and cons of vaccination, there are two levels that need to be carried out proportionally, and the Indonesian Ulema Council has issued a specific fatwa. "Vaccines that are used preventively are justified in syar'i as long as they comply with sharia provisions". (Binti, 2020).

The Fatwa Commission of the Indonesian Ulema Council has issued a fatwa regarding the halalness of the Covid-19 vaccine made by Sinovac. This fatwa was issued following the issuance of Emergency Use Authorization (EUA) by the Food and Drug Supervisory Agency (BPOM), Monday (11/1/2021). In the MUI Fatwa Number: 02 of 2021 concerning Covid-19 Vaccine Products from Sinovac Life Science Co. LTD China and PT Bio Farma (Persero), MUI stated that the vaccine was legal and halal. The vaccine may be used for Muslims as long as its safety is guaranteed according to a credible and competent expert. There are several bases used by MUI in determining the halalness of the Sinovac vaccine (Aida, 2020). 
The government should intensify vaccine socialization to the public while still emphasizing the importance of enforcing health protocols. Moreover, based on the results of a government survey, there are still groups of people in the community who are concerned about the safety and effectiveness of vaccines, who express distrust of vaccines and question the halalness of vaccines. Another fact, some people are not willing to pay for vaccines. The government has created a free vaccine program and independent vaccine. (Indonesia, 2020).

The pros and cons that occur in society are new problems faced by the government. Several studies on vaccination carried out in various countries reveal that increasing public knowledge about vaccination will improve vaccine status and affect the success of the vaccination program (Yuningsih, 2020). With the pros and cons of the Covid-19 Sinovac virus prevention vaccination program, it is necessary to socialize by educating the public. There needs to be the involvement of all elements of society, such as local area managers, schools, and others, also involving all mass media and social media in the success of the Covid-19 Vaccination program. The purpose of this study was to determine how much the effectiveness of the campaign for the use of the Covid-19 Sinovac vaccine carried out by the Government on people's behavior in receiving vaccines.

\section{LITERATURE REVIEW}

Campaigns are persuasive activities aimed at influencing patterns of thinking, behaving, and behaving as expected. Communication campaigns have the aim of informing, persuading, and motivating changes in audience behavior. Hovland and Weis argue that a change in a person's attitude is more influential if it is caused by a highly credible communicator. Therefore, communicators play an important role in the campaign (S. Soemirat, 2014).

(SAS Soemirat, 2014) call the campaign an organized behavior, it must be planned and implemented systematically and carefully. This shows that campaign activities require a touch of management, namely designing, implementing, controlling, and evaluating program activities in a rational, realistic, efficient, and effective manner. From the start, campaign activities always cover the stages of planning, implementation, and evaluation. The difference is that at present the various stages are standardized and formalized by the term campaign management effectively and efficiently by utilizing all available resources to achieve predetermined goals. The inclusion of a managerial element in campaign management is expected to have a more open and bigger chance of achieving campaign objectives.

Campaign objectives are very diverse and differ from one organization to another. (Normawati et al., 2018) in Venus says the three aspects of "3A", namely, awareness, attitude, and actions. These three aspects are interrelated and are targets of influence (targets of 36 influences) must be achieved gradually so that a condition of change can be created. (Cangara, 2017) Campaign planning is a stage that must be done so that the campaign can achieve the desired goals. The main function of planning in a campaign is to create order and clarity of direction of action.

Behavior as a reaction is simple or complex and is an expression of a person's attitude. According to Skinner, the behavior is a person's response or reaction to external stimuli. (Notoatmodjo, 2010) in. Behavior is an activity or human activity, which can be observed directly or that cannot be observed by outsiders (Notoatmodjo, 2010). Behavior is an individual's response or reaction to stimuli or the environment. Behavior is the action or action of an organism that can be observed and can even be studied (Notoatmodjo, 2010).

The Process of Forming Behavior From experience and research it is evident that things that are based on knowledge will be more lasting than behaviors that are not based on knowledge. (Notoatmodjo, 2012) reveal before people adopt new behaviors (new behavior), in the person a sequential process occurs, abbreviated as AIETA which means:

1. Awareness (consciousness), that is, the person realizes in the sense of knowing the stimulus (object) first.

2. Interest, namely people starting to be attracted to the stimulus.

3. Evaluation (considering whether or not the stimulus is good for him). This means that the respondent's attitude is even better.

4. During the trial, people have started trying new behaviors.

5. Adoption, the subject has a new behavior by their knowledge, awareness, and attitude towards the stimulus.

If the acceptance of new behavior or the adoption of behavior through a process like this is based on knowledge, awareness of a positive attitude, then the behavior long-lasting. Conversely, if a behavior is not based on knowledge and awareness, it will not last long. 
The Sinovac vaccine is an inactivated vaccine or dead virus. In short, the inactivated vaccine is a vaccine that uses a weak or inactivated version of the virus to provoke an immune response. Inactivated vaccines require several doses overtime to gain sustained immunity against the disease. Inactivated vaccines have been used for Hepatitis A, Flu, Polio, and Rabies. Bio Farma is working with Sinovac to produce a vaccine called CoronaVac. Therefore, a phase III clinical trial was conducted in Indonesia. Efficacy based on clinical trials in Bandung was recorded at 65.3 percent, meeting the requirements of the WHO world health organization, which is above 50 percent. Side effects were mild-moderate and could recover (World Health Organization, 2020)

\section{RESEARCH METHODOLOGY}

This research uses a quantitative approach, with the nature of the research is explanatory research. This research method uses a type of survey research. The population in this study were members of the Istiqomah Taklim Council, and the sample used in this study amounted to 30 people, this is by the opinion of Gay \& Dichl, the sample size for correlation research is at least 30 people.

Using non-probability sampling, with the Accidental Sampling technique, which is sampling based on the fact that they happen to appear.

\section{RESULTS OF RESEARCH AND DISCUSSION}

Based on the results of the validity test on the campaign effectiveness instrument for the use of the Covid-19 Sinovac vaccine, it is known that the results are that all 13 instruments are declared valid. The determination of validity is determined by the $r$ count $\geq r$ table ( $r$ table 0.361 for the count number $n=30$ ).

Table 1. Case Processing Summary

\begin{tabular}{llr|r} 
& & $\mathrm{N}$ & \multicolumn{2}{c}{$\%$} \\
\hline \multirow{3}{*}{ Cases } & Valid & 30 & 100.0 \\
\cline { 2 - 5 } & Excluded & 0 & .0 \\
\cline { 2 - 4 } & Total & 30 & 100.0 \\
\hline
\end{tabular}

a. Listwise deletion based on all variables in the procedure.

As for the reliability level of the instrument with the number of respondents as many as 30 respondents, and with the instrument of statement items as many as 13 items, the Cronbach's Alpha value is 0.975 , so that the instrument is declared to have a high or very reliable level of reliability.

Table 2. Reliability Statistics

\begin{tabular}{|c|c|}
\hline $\begin{array}{c}\text { Cronbach's } \\
\text { Alpha }\end{array}$ & $\mathrm{N}$ of Items \\
\hline .975 & 13 \\
\hline
\end{tabular}

All 18 instruments of Communication Engineering Behavior were declared valid. Where the determination of validity is determined by the $r$ count $\geq r$ table ( $r$ table 0.361 for the count number $n=30$ ). 
Table 3. Case Processing Summary

\begin{tabular}{|c|c|c|c|c|c|}
\hline \multirow{4}{*}{$\begin{array}{l}\text { The reliability level } \\
\text { Communication Engineering } \\
\text { respondents and a total of } 18\end{array}$} & & & & $\%$ & \multirow{5}{*}{$\begin{array}{l}\text { of the instrument from } \\
\text { Behavior, with a total of } 30 \\
\text { items of instruments, the } \\
0.965 \text {, so that the instrument } \\
\text { reliable level of reliability. }\end{array}$} \\
\hline & \multirow[t]{3}{*}{ Cases } & Valid & 30 & 100.0 & \\
\hline & & Excluded & 0 & .0 & \\
\hline & & Total & 30 & 100.0 & \\
\hline $\begin{array}{l}\text { Cronbach's Alpha value is } \\
\text { is declared a high or very }\end{array}$ & \multicolumn{4}{|c|}{$\begin{array}{l}\text { a. Listwise deletion based on all variables in the } \\
\text { procedure. }\end{array}$} & \\
\hline
\end{tabular}

Table 4. Reliability Statistics

Cronbach's

\begin{tabular}{l|l} 
Alpha & $\mathrm{N}$ of Items \\
\hline
\end{tabular}

$.965 \quad 18$

\section{Simple Correlation Test}

The correlation test was carried out to determine the relationship between the effectiveness of the Covid19 Sinovac Vaccine Campaign and Communication Engineering Behavior. with the Rank Spearman formula to determine the correlation coefficient between variable $\mathrm{X}$ and variable Y. Here are the results of the calculation of the correlation test:

Table 5. Correlation Test Calculation Results

\section{Correlations}

\begin{tabular}{|c|c|c|c|}
\hline \\
\hline & & $\begin{array}{c}\text { CAMPAIGN } \\
\text { EFFECTIVENESS }\end{array}$ & $\begin{array}{l}\text { COMMUNICAT } \\
\text { ION } \\
\text { ENGINEERING } \\
\text { BEHAVIOR }\end{array}$ \\
\hline \multirow{3}{*}{$\begin{array}{l}\text { EFFECTIVENESS } \\
\text { CAMPAIGN }\end{array}$} & Pearson Correlation & 1 & $.827 * *$ \\
\hline & Sig. (2-tailed) & & .000 \\
\hline & $\mathrm{N}$ & 30 & 30 \\
\hline \multirow{3}{*}{$\begin{array}{l}\text { BEHAVIOR } \\
\text { PUBLIC }\end{array}$} & Pearson Correlation & $.827 * *$ & 1 \\
\hline & Sig. (2-tailed) & .000 & \\
\hline & $\mathrm{N}$ & 30 & 30 \\
\hline
\end{tabular}

Source: Data processed from the SPSS questionnaire 26

Based on the table above, it is known that the correlation coefficient value is $r=0.827$, so it means that this value has a very strong relationship because it is between the interpretation value of $0.800-0.999$. So it can be concluded that there is a very strong relationship between the effectiveness of the campaign for the use of the Covid-19 Sinovac vaccine and people's behavior.

\section{Simple Linear Regression Test}

The regression test is performed to predict how high the value of the dependent variable (Y) will be if the independent variable $(\mathrm{X})$ is changed. 
Table 6. Regression Calculation Results Coefficients

\begin{tabular}{|c|c|c|c|c|c|c|}
\hline \multirow[b]{2}{*}{ Model } & & \multicolumn{2}{|c|}{$\begin{array}{c}\text { Unstandardized } \\
\text { Coefficients }\end{array}$} & \multirow{2}{*}{$\begin{array}{c}\text { Standardized } \\
\text { Coefficients } \\
\text { Beta }\end{array}$} & \multirow[b]{2}{*}{$\mathrm{T}$} & \multirow[b]{2}{*}{ Sig. } \\
\hline & & $\mathrm{B}$ & Std. Error & & & \\
\hline 1 & (Constant) & 12,979 & 9,602 & & 1,352 & .180 \\
\hline & $\begin{array}{l}\text { CAMPAIGN } \\
\text { EFFECTIVENESS }\end{array}$ & 1,367 & .121 & .827 & 11,297 & .000 \\
\hline
\end{tabular}

Information:

$$
Y=a+b X
$$

$Y^{\prime}:$ The predicted value

$a$ : Constant or when the value of $\mathrm{X}=0$

$b$ : Regression coefficient

$X$ : The value of the independent variable

Then :

$$
Y=12,979+1,367 X
$$

This equation can be interpreted as follows:

a. The constant value (a) is 12,979 , meaning that the consistent value of the Y variable or people's behavior is 12,979

b. The regression coefficient of campaign effectiveness yields 1,367 results, which means that for every $1 \%$ increase in the value of the campaign effectiveness variable for the use of the Covid-19 Sinovac vaccine, the value of the Communication Engineering Behavior variable will increase by 1.367 .

c. The regression coefficient number has a positive value, it can be understood that the direction of the effect of the effectiveness of the campaign using the Covid-19 Sinovac vaccine on people's behavior is positive.

\section{Determination Coefficient Test}

The calculation of the amount of contribution given by the effectiveness of the campaign for the use of the Covid-19 Sinovac vaccine to the variable of people's behavior can be seen in the following table:

Table 7. Determination Coefficient Test Calculation Results

\begin{tabular}{ll|l|l|r} 
& & \multicolumn{2}{c}{ Model Summary } \\
Model & R & R Square & \multicolumn{1}{c}{$\begin{array}{c}\text { Adjusted R } \\
\text { Square }\end{array}$} & $\begin{array}{c}\text { Std. An error of } \\
\text { the Estimate }\end{array}$ \\
\hline 1 & $.840 \mathrm{a}$ & .566 & .561 & 10.28682 \\
\hline
\end{tabular}

a. Predictors: (Constant) CAMPAIGN EFFECTIVENESS

Source: Data processed from the SPSS questionnaire 26

To find out the magnitude of the contribution of the influence of the effectiveness of the campaign using the Covid-19 Sinovac vaccine on people's behavior, the coefficient of determination is calculated by squaring the correlation results, then multiplying by $100 \%$, as in the following formula:

$$
\mathrm{Kd}=\mathbf{r}^{2} \times 100 \%
$$

Information:

$\mathrm{Kd}=$ The coefficient of determination

$\mathrm{r}=$ Correlation coefficient 
$\mathrm{Kd}$

$$
\begin{aligned}
& =0.840^{2} \times 100 \% \\
& =0,706 \times 100 \% \\
& =70.6 \%
\end{aligned}
$$

Based on the calculation of the results of determination, it can be seen that the correlation value $(\mathrm{r})=$ 0.827 and the R Square value (squaring the correlation value), which is $0.840=70.6 \%$. So it can be concluded that $70.6 \%$ of people's behavior is influenced by the effectiveness of the campaign for the use of the Covid-19 Sinovac vaccine, and as much as $29.4 \%$ is influenced by other factors that are not studied.

\section{Hypothesis testing}

Hypothesis testing was conducted to determine whether the effectiveness of the campaign using the Covid19 Sinovac vaccine had a significant effect on people's behavior. The basis for decision making is to compare $t$ count with $\mathrm{t}$ table, which is as follows:

a. If $t$ count $<t$ table, then Ho is accepted and Ha is rejected.

b. If $\mathrm{t}>\mathrm{t}$ table, then Ho is rejected and $\mathrm{Ha}$ is accepted.

\begin{tabular}{|c|c|c|c|c|c|c|}
\hline & \multirow[b]{2}{*}{ Model } & \multicolumn{2}{|c|}{$\begin{array}{c}\text { Unstandardized } \\
\text { Coefficients }\end{array}$} & \multirow{2}{*}{$\begin{array}{c}\text { Standardized } \\
\text { Coefficients } \\
\text { Beta }\end{array}$} & \multirow[b]{2}{*}{$\mathrm{T}$} & \multirow[b]{2}{*}{ Sig. } \\
\hline & & $\mathrm{B}$ & Std. Error & & & \\
\hline \multirow[t]{2}{*}{1} & (Constant) & 12,979 & 9,602 & & 1,352 & .180 \\
\hline & $\begin{array}{c}\text { CAMPAIGN } \\
\text { EFFECTIVEN } \\
\text { ESS }\end{array}$ & 1,367 & .121 & .752 & 11,297 & .000 \\
\hline
\end{tabular}

Table 8. Hypothesis Calculation Results Table Coefficients

Determination of significant conclusions by comparing t count with $\mathrm{t}$ table, namely the determination of the level of significance. From the $t$ table, the value is determined at a significant level of 0.10 and $\mathrm{df}=\mathrm{n}-2$, namely $30-2=28$. Thus the $t$ table is 0.683335 .

The basis of decision making is to compare $t$ count with $t$ table:

1. If $\mathrm{t}>\mathrm{t}$ table, then Ho is rejected and Ha is accepted (has a big effect)

2. If $\mathrm{t}$ count $<\mathrm{t}$ table, then Ho is accepted and $\mathrm{Ha}$ is rejected (no big effect)

Determination of significant conclusions by comparing $t$ count 11.878 with $t$ table, namely the determination of the level of significance. From the $t$ table, the value is determined at a significant level of 0.10 and $\mathrm{df}=\mathrm{n}-2$, namely $30-2=28$. Thus the $\mathrm{t}$ table is 0.683335 . Thus $\mathrm{t}$ count is greater than the $\mathrm{t}$ table which means that $\mathrm{Ha}$ is accepted and $\mathrm{H} 0$ is rejected. This means that the effectiveness of the campaign for using the Covid-19 Sinovac vaccine has a major effect on public behavior.

\section{CONCLUSION}

Based on the research results, it can be concluded as follows:

The entire instrument, both the effectiveness of the campaign for the use of the Covid-19 Sinovac vaccine, and the people's behavior is declared valid, and very reliable, so that the research instrument is very reliable and can be generalized to all populations throughout Indonesia. There is a very strong correlation between the effectiveness of the campaign for the use of the Covid-19 Sinovac vaccine and the behavior of the community in receiving the vaccine with a correlation coefficient value of rcount 0.827 .

The campaign effectiveness of using the Covid-19 Sinovac vaccine has a major or significant effect on people's behavior in receiving the vaccine. $70.6 \%$ of people's behavior is influenced by the effectiveness of the Campaign for the use of the Covid-19 Sinovac vaccine. An effective campaign in the use of the Covid-19 Sinovac vaccine, which is often carried out by the Government through various communication media, has made the public know various information and benefits of the Sinovac vaccine so that many initially refused to be willing to be vaccinated.

\section{SUGGESTION}

Be more active in campaigning for the use of the covid-19 vaccine through various communication media such as conventional media and social media to reach all communities to remote areas in a faster time. Using a campaign strategy that is more effective in reaching the wider community, thereby eliminating public doubts about being vaccinated with the Sinovac vaccine. 


\section{REFERENCE}

1. Aida, NR (2020). Corona Virus Update in the World: 214,894 Infected People, 83,313 Healed, 8,732 Died. Kompas.Com.

2. Asrorun. (2020). Pros-Cons of Covid-19 Vaccination Here's MUI's Response. Media Indonesia.Com.

3. Baum, F., Narayan, R., Sanders, D., Patel, V., \& Quizhpe, A. (2009). Social vaccines to resist and change unhealthy social and economic structures: A useful metaphor for health promotion. In Health Promotion International. https://doi.org/10.1093/heapro/dap026

4. Binti, M. (2020). Pros-Cons of Covid-19 Vaccination Here's MUI's Response. Media Indonesia.Com.

5. Cangara, H. (2017). Communication Planning and Strategy. In Jakarta: PT Rajagrafindo Persada.

6. Deutsch, J. (2020). "How Long Will It Take to Develop a Coronavirus Vaccine?" POLITICO.

7. Dewi, WAF (2020). Impact of COVID-19 on Online Learning Implementation in Primary Schools. EDUCATIVE: JOURNAL OF EDUCATION SCIENCE. https://doi.org/10.31004/edukatif.v2il.89

8. Drishti. (2020). Governance: Social Vaccine. Drishti News.

9. Indonesia, M. (2020). Vaccines Need Socialization. Media Indonesia.Com.

10. Juditha, C. (2020). Communication Engineering Behavior Related to the Spread of the Covid-19 People Hoax. Journal of Pekommas.

11. Koesmawardhani, NW (2020). Government Sets Corona Disaster Emergency Period until May 29, 2020. Detiknews.

12. Lucia Rizka. (2021). Discussion on the Halalness and Safety of the COVID-19 Vaccine. Tempo.

13. Mahatma Chryshna. (2020). The Politicization of Vaccines and the Covid-19 Vaccination Program in Indonesia. Compass.

14. Normawati, Maryam, S., \& Priliantini, A. (2018). The effect of the "Let's disconnect to connect" campaign on anti-phubbing attitudes (Survey on followers of the official Starbucks Indonesia Line account). Journal of Communication, Media and Informatics.

15. Notoatmodjo. (2010). Anchovies Health Promotion And Applications. In Pt. Rineka Cipta.

16. Notoatmodjo, S. (2012). Health Promotion \& Behavioral Sciences. In Jakarta: Rineka Cipta.

17. Rahmi Yuningsih. (2020). Brief Information on Social Welfare "Coronavac Clinical Trial and Mass Covid-19 Vaccination Plan in Indonesia." 112 (16).

18. Rizki, RV (2020). Get to know Sinovac, the Chinese company that sent the corona vaccine to Indonesia. Contan.Co.Id.

19. Soemirat, S. (2014). Persuasive Communication. Persuasive Communication.

20. Soemirat, SAS (2014). Philosophy and Basic Concepts of Persuasive Communication. Persuasive Communication.

21. World Health Organization. (2020). Clinical management of severe acute respiratory infection when novel coronavirus ( $\mathrm{nCoV}$ ) infection is suspected. Who.

22. worldometers.info. (2020). WorldoMeter: Real-Time World Statistics. Current World Population. WorldoMeter. Accessed December 24, 2020.

23. Yuningsih, R. (2020). Coronavac Clinical Trial and Mass Covid-19 Vaccination Plan in Indonesia. Public BKD DPR RI. 